\title{
Geographic distribution of HCV genotypes in Libya and analysis of risk factors involved in their transmission
}

\author{
Mohamed A Daw ${ }^{1,2^{*}}$, Abdallah El-Bouzedi ${ }^{3}$ and Aghnaya A Dau ${ }^{4}$
}

\begin{abstract}
Background: Hepatitis C virus (HCV) genotypes have been shown to be differently distributed between distinct geographical areas. Libya is a large country has the longest coast in the Mediterranean basin. Information regarding hepatitis C genotypes and subtypes circulating in Libya are not well known. The objectives of this study were to determine the frequency of various HCV genotypes cross Libya and the demographic and attributable risk factors associated with HCV transmission among Libyan population.
\end{abstract}

Methods: A cross-sectional study was carried out on patients with recently confirmed HCV infection. A total of 3,227 serum samples enrolled at 19 collection center cross Libya. 1,756 belonged to Tripoli region, 452 to West region 355 to North region, 181 South regions and 483 East region. The samples were tested by type specific genotyping assay and correlated with demographic and potential risk factors within the studied populations.

Results: A total of 20 discrete genotypes and subtypes were identified among the Libyan population ranging from 11.5 to $0.3 \%$ cross the country. Genotype 1 was the most frequent among all regions (19.7-40.5 \%), reaching the highest value in Tripoli region, followed by genotype 4 which was more prevalent in the South (49.3\%) and West (40.0 \%) regions. Genotype 3, was higher in Tripoli (21.3\%) and East (15.9\%) regions while genotype 2, common in North (23.6\%) and South (22.5\%) regions. However, we found evidence that there is a changing relative prevalence of HCV genotypes in relation to age, gender and the mode of transmission which is reflected in the predominance of certain genotypes among Libyan population.

Conclusions: Different HCV genotypes were isolated form Libyan population including newly emerged ones. The prevalence of the genotypes varied by geographic region and influenced by demographic and risk factors. Knowing the frequency and distribution of the genotypes would provide key information on understanding the spread of HCV in Libya and this could be greatly reflected on national plans and future strategies for infection prevention.

Keywords: Libya, Hepatitis C virus, HCV subtypes, Genotypic variability, Africa

\section{Background}

Hepatitis $\mathrm{C}$ virus $(\mathrm{HCV})$ is a leading cause of chronic viral hepatitis, liver cirrhosis and hepatocellular carcinoma. Such implications have great, clinical, epidemiological and economic burdens worldwide particularly among developing countries [1,2]. Relative risk factors as well as intervention and preventions programs are greatly

\footnotetext{
*Correspondence: mohamedadaw@gmail.com

${ }^{1}$ Department of Medical Microbiology, Faculty of Medicine, Tripoli

University, 82668 Tripoli, Libya

Full list of author information is available at the end of the article
}

influenced by regional variation of the $\mathrm{HCV}$ genotypes [3]. Genotyping plays an important role in the pathogenicity and hepatocarcinogenic potential of hepatitis $C$ infection. Indeed pathological consequences and therapeutic responses has been greatly influenced by the $\mathrm{HCV}$ genotypes [4].

Different studies have shown that HCV genotype 1 has been associated with lower rates of response to peginterferon-based regimens compared with genotypes 2 and 3. Furthermore, infections with genotype 1a responds less than genotype $1 \mathrm{~b}$ to treatment with peginterferon/ 
ribavirin and to triple regimens that include telaprevir or boceprevir [5, 6]. Differences in pathogenicity and hepatocarcinogenic potential of the various genotypes of HCV were also reported. Raimondi et al. found that there was an increased risk of HCC in patients infected with genotype $1 \mathrm{~b}$, with or without the presence of cirrhosis [7]. Other studies also found both subtypes within genotype 1 to confer heightened risk of histopathological damage, concomitant progression to $\mathrm{HCC}$, and to a lesser extent, persistence of infection [8, 9]. Many of these studies are from geographical regions where such genotypes predominate, hence then, further studies from different regions are needed.

The relative prevalence of $\mathrm{HCV}$ genotyping varies geographically and demographically worldwide. HCV genotypes $1 \mathrm{a}$ and $1 \mathrm{~b}$, are the most frequent genotypes in the North American and Europe [10, 11], and genotypes 5 and 6 seem to be confined to South Africa and Hong Kong [12, 13], respectively. HCV genotypes 7, 8, and 9 have been identified only in Vietnamese patients $[14,15]$ and genotypes 10 and 11 were identified in patients from Indonesia [16]. HCV genotypes and subtypes within the country also vary according to ethnicity and age. However, world integration and recent massive population displacement has lead to introduction of HCV genotype among a certain areas that not commonly known. HCV genotype distribution has been used for the identification of populations' origin of HCV infection, examination of historical trends in characteristics of $\mathrm{HCV}$ infection and making inferences regarding routes of $\mathrm{HCV}$ transmission [17].

Hepatitis $C$ virus infection is a major public health concern among African countries, they have the highest prevalence rates of $\mathrm{HCV}$ in the world, ranging from 1 to $26 \%$ [2, 18]. Over 28 million people are chronically infected with $\mathrm{HCV}$ in this continent, and it is difficult to speculate about current and future trends [19]. HCV genotyping rarely studied in Africa, however, few studies were carried on a restricted populations in North Africa have shown diversity of HCV genotyping among these countries [20]. Therefore, population based studies are needed in order to plan for future prevention and intervention programs. Libya is the second largest country in Africa, with the longest coast facing the Southern European Union [21]. Bordering six different countries, where $\mathrm{HCV}$ has been considered to be endemic $[22,23]$. In recent years the country has attracted worldwide attention because many Africans transit through it to enter Southern Europe illegally, with the possibility of transmitting infection in transit, or at the destination. Hence then a wide variation in the frequencies of $\mathrm{HCV}$ genotypes would be expected among Libyan territory.
In Libya HCV has been well studied, recently a comprehensive study including $1 \%$ of the total population was carried. $\mathrm{HCV}$ prevalence ranged from 0.9 to $1.2 \%$. It was most prevalent among intravenous drug users $(7.4 \%)$ and less prevalent but still substantial in those undergoing blood transfusion (2.7\%), surgical operation (2.3\%) or hospital admission (1.9\%) [24]. However, few studies had lend themselves studying HCV genotype frequencies in small cohorts or restricted populations, but information concerning the distribution of viral genotypes and demographic and risk factors that influence HCV infection are limited [20]. The objectives of this study were aimed to determine the distribution of various HCV genotypes and subtypes present in different geo-graphical regions of Libya and the association with various risk factors involved in the transmission $\mathrm{HCV}$ infection among Libyan population.

\section{Methods}

\section{Study population}

Serum samples were collected from different patients with chronic HCV from all Libyan provinces based on the population proportion. Libya is a large country with a total geographic area; $1,775,500 \mathrm{~km}^{2}$ (square kilometers). The estimated Libyan population based on the consensus of 2006 was found to be 6,154,623 million. More than half of population were located in Tripoli region and less than a million in the Eastern region, the others are scattered over the vast areas of the country. A total of 3,227 different sera samples were collected from each of the five regions as following:

- Tripoli Region (TR) represented by five districts [number of isolates $(\mathrm{n})=1,756]$ including: Tajoura, Old City, Zwara, Alzawia, and Tarhona.

- West Region (WR) represented by three districts $(\mathrm{n})=452$ including: Navosa Mountains, Garian and Ghadams.

- North Region (NR) represented by four districts $(\mathrm{n})=355$ including: Sert, Musrata, Alkoms and Baniwaled.

- South Region (SR) represented by four districts $(\mathrm{n})=181$ including: Aljofra, Ashati, Murzak and Sebha.

- East Region (ER) represented by three districts (n) $=483$ including: Benghazi, Albtnan and Alkufra.

\section{Laboratory tests and HCV genotyping}

All the serum samples were received along with specifically designed data sheets at Department of Medical Microbiology, Faculty of Medicine, Tripoli from 19 tertiary collection of the 5 regions involved. A written informed consent was taken from each patient and the 
data sheet contained demographic information including age, gender, year of diagnosis and risk factors for HCV such as history of blood transfusion, intravenous drug abuse (IVDA), history of surgical intervention, family history of $\mathrm{HCV}$ positive and history of promiscuity and dental procedure. Those patients who denied any risk factors were assigned to be as an; unknown group. Each serum specimen was re-tested positive for $\mathrm{HCV}$ antibody (anti$\mathrm{HCV}$ ) using 3rd generation commercial Enzyme Linked Immunosorbent Assays as previously described by Daw and El-Bouzedi [24]. HCV genotyping was carried out using type-specific $\mathrm{HCV}$ genotyping method [20]. All the different genotypes of $\mathrm{HCV}$ were tested and primers for genotypes 1a, 1b, 1c, 3a, 3c and 4 and $2 \mathrm{a}, 2 \mathrm{c}, 3 \mathrm{~b}, 5 \mathrm{a}$, and 6a primers were incorporated. Hence then $\mathrm{HCV}$ genotype for each sample was determined by identifying the HCV genotype-specific PCR band [20].

\section{Statistical analysis}

Data were coded and entered into a data base, which was then cleaned and verified. Data were analysed by using the Chi square test with Yates' correction or Student's $t$-test for univariate analysis. The results for all variables were given in the form of rates (\%). A multivariate analysis was conducted using logistic regression in order to verify which variables statistically had an influence on HCV infection such as gender (male vs. female), IV drug abuser (yes or no), blood transfusion (yes o $r$ no) surgical Intervention and blood transfusion (yes or no), dental care (yes or no); promiscuity (yes or no). The data were analyzed using SPSS version 11.5 to identify the distribution of different genotypes and it $\mathrm{s}$ association with gender, age, year of diagnosis and risk factors [20].

\section{Ethical approval}

The study was approved by the Libyan National Ethical Committee (Approval No. LY NS; HCV-G-399773). It was conducted in accordance with the Helsinki Declaration [25] and under the supervision of the Faculty of Medicine, Tripoli, Libya. All participants signed an informed consent form witnessed by the local health office before collection of data and blood samples. The questionnaire used to collect demographic and epidemiological data was anonymous and linked to the blood sample tube only by a code.

\section{Results}

A total of 3,227 anti-HCV positive sera were received from all the five regions of the country. Out of these $1,501(46 \%)$ samples were found positive by HCV qualitative PCR with viral load $>500 \mathrm{IU} / \mathrm{ml}$ were tested by type-specific genotyping assay. Out of 1,501 patients, $976(65 \%)$ were males and $525(35 \%)$ were females with an average age of $37.8 \pm 13.4$ years. Total of 817 (54.4\%) belongs to Tripoli region, $161(10.7 \%)$ to North region, 210 (13.9 \%) West region, 71 (4.7 \%) South region, 242 (15.1 \%) East region. The distribution of HCV genotypes was shown in Table 1; a total of 20 different HCV genotypes and subtypes were found among the Libyan population. The distribution of such types was found to be as follows: 371 (11.5\%) were genotype 4; $219(6.7 \%)$ genotype 1; 205 (6.35 \%) genotype 1b; 199 (6.17\%) genotype 3a; 135 (4.18\%) genotype 1a; 118 (3.66 \%) genotype $2 ;(82 \%)$ genotype $2 \mathrm{a} / \mathrm{c} ; 68$ (2.11) genotype $4 \mathrm{c} / \mathrm{d} ; 40$ (1.24 \%) genotype $3 ; 19$ (0.59 \%) genotype $4 \mathrm{~h} ; 15$ (0.46 \%) genotype $2 \mathrm{~b} ; 10(0.31 \%)$ genotype $2 \mathrm{a} ; 7(0.22 \%)$ genotype $4 \mathrm{e}$; and $4(0.12 \%)$ genotype $4 \mathrm{a}$. Few stains were isolated at a low count $(0.3 \%)$ these include genotype $4 \mathrm{~b}, 4 \mathrm{f}, 4 \mathrm{~h}$, $4 \mathrm{~d}, 4 \mathrm{a} / \mathrm{c}$ and HCV genotype 5 though genotype 6 was not reported.

HCV genotype 1, 2, 3 and 4 were isolated from all over Libya, Fig. 1 shows the distribution of such genotypes according to the patients residential regions. Genotype 1 is the most common genotype isolated from Tripoli (40.5 \%) and East regions (38.4\%), followed by the West $(35.2 \%)$ and North (31.1\%) regions and less reported in the South region (19.7\%); Genotype 4, South (49.3\%) and West region (40.0\%), followed by both East and North

Table 1 Distribution of HCV genotypes and subtypes among Libyan populations

\begin{tabular}{|c|c|c|c|}
\hline \multirow[t]{2}{*}{ Type/subtype } & \multirow{2}{*}{$\begin{array}{l}\text { Total no of isolates } \\
(\%)\end{array}$} & \multicolumn{2}{|c|}{ Distribution among (\%) } \\
\hline & & Male & Female \\
\hline 1 & $219(6.79)$ & $160(7.26)$ & $59(5.77)$ \\
\hline $1 \mathrm{a}$ & $135(4.18)$ & $103(4.67)$ & $32(3.13)$ \\
\hline $1 b$ & $205(6.35)$ & $110(4.99)$ & $95(9.29)$ \\
\hline $1 \mathrm{a} / \mathrm{b}$ & $3(0.09)$ & $2(0.09)$ & $1(0.10)$ \\
\hline 2 & $118(3.66)$ & $72(3.27)$ & $46(4.50)$ \\
\hline $2 a$ & $10(0.31)$ & $4(0.18)$ & $6(0.59)$ \\
\hline $2 b$ & $15(0.46)$ & $8(0.36)$ & $7(0.68)$ \\
\hline $2 a / c$ & $83(2.57)$ & $49(2.22)$ & $34(3.32)$ \\
\hline 3 & $40(1.24)$ & $33(1.50)$ & $7(0.68)$ \\
\hline $3 a$ & $199(6.17)$ & $170(7.71)$ & $29(2.83)$ \\
\hline 4 & $371(11.50)$ & $216(9.80)$ & $155(15.15)$ \\
\hline $4 b$ & $4(0.12)$ & $1(0.14)$ & $0(0.10)$ \\
\hline $4 \mathrm{e}$ & $1(0.03)$ & $6(0.05)$ & $1(0.00)$ \\
\hline $4 \mathrm{~F}$ & $7(0.22)$ & $1(0.27)$ & $0(0.10)$ \\
\hline $4 h$ & $19(0.59)$ & $8(0.36)$ & $11(1.08)$ \\
\hline $4 a / c$ & $1(0.03)$ & $0(0.00)$ & $1(0.10)$ \\
\hline $4 c / d$ & $68(2.11)$ & $29(1.32)$ & $39(3.81)$ \\
\hline $4 d$ & $1(0.03)$ & $1(0.05)$ & $0(0.00)$ \\
\hline 5 & $1(0.03)$ & $1(0.05)$ & $0(0.00)$ \\
\hline Unknown & $1,726(53)$ & $1,227(55.67)$ & 499 (48.78) \\
\hline Total & $3,227(100.00)$ & $2,204(100.00)$ & $1,023(100.00)$ \\
\hline
\end{tabular}




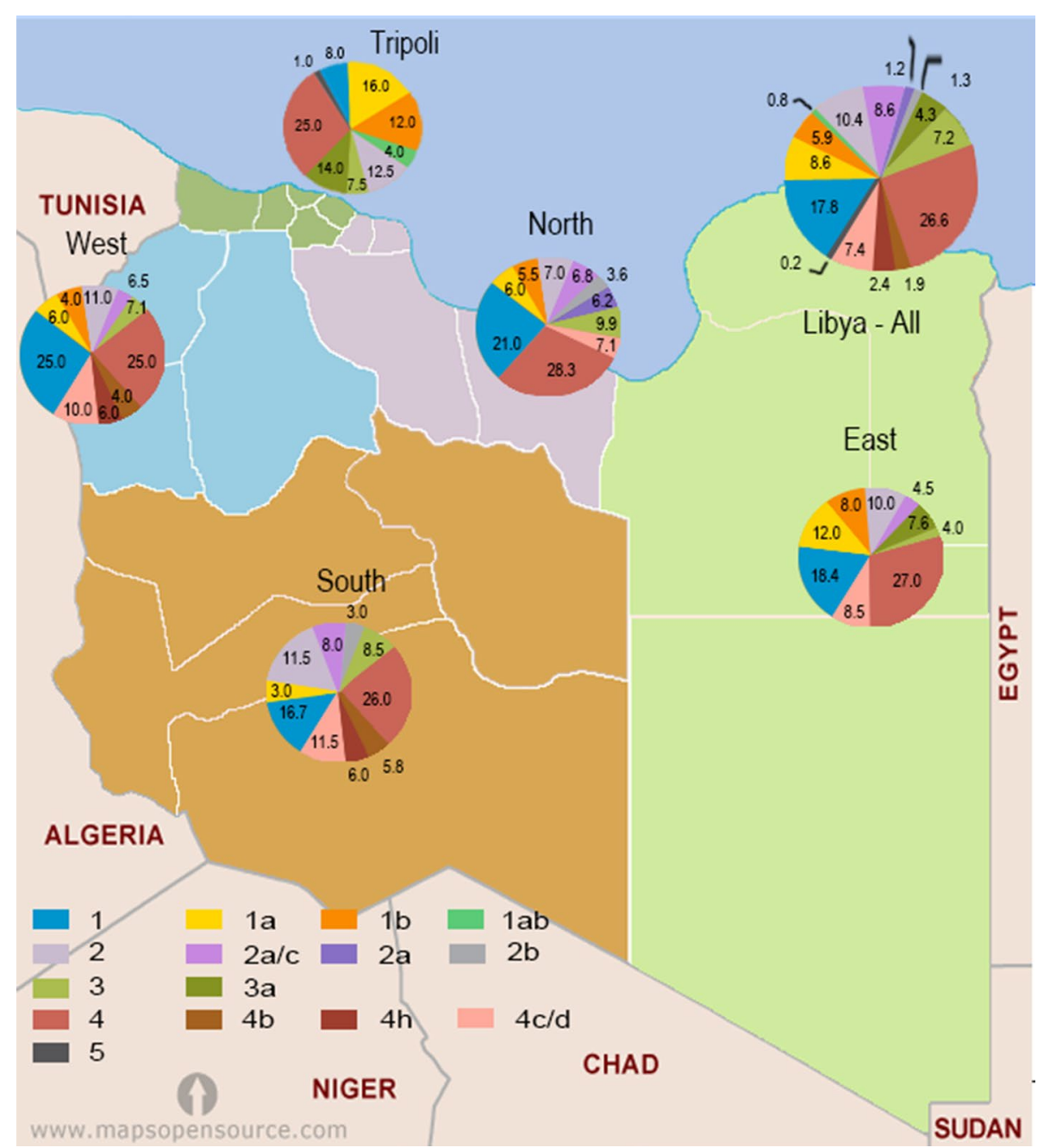

Fig. 1 Geographical distribution of HCV genotypes according to the Libyan regions (color-coded). Data indicate percentage of patients infected by genotype in each region.

(35.5\%) and less among Tripoli region (25.9); Genotype 3, Tripoli $(21.3 \%)$ and East (15.9\%) and varied from 7.1 to $11.6 \%$ among other regions; Genotype 2, North (23.6\%) and South (22.5\%) and from 12.2 to $14.5 \%$ among other regions. HCV genotypes were found to be variables among the Libyan region involved $(P<0.26)$ though no variation within the provinces of each region.

Table 2 illustrates the association between HCV genotypes and demographic variables (i.e. age distribution) among Libyan population. HCV genotype 1 was more frequent genotype among all age groups ranged from 25.3 to $88 \%$, followed by genotype 4 ranged from 8 to $37.6 \%$ while genotype 2 and 3 are less frequent ranged from 0 to $45.5 \%$ and 4 to $25.5 \%$ respectively. Furthermore, $\mathrm{HCV}$ genotype 1 was the highest among those below ( $<20$ years); $88 \%$ within (0-9 years) and $78 \%$ of (1019 years). $\mathrm{HCV}$ genotype 2 was three times $(\mathrm{OR}=0.2$;
Table 2 The distribution of HCV-genotypes among different age group

\begin{tabular}{lrccrl} 
Age group & Genotype $\mathbf{1}$ & Genotype $\mathbf{2}$ & Genotype & \multicolumn{1}{l}{ Genotype $\mathbf{4}$} & Total \\
\hline $0-9$ & $22(88.0)$ & $0(0.0)$ & $1(4.0)$ & $2(8.0)$ & 25 \\
$10-19$ & $46(78.0)$ & $2(3.4)$ & $2(3.4)$ & $9(15.3)$ & 59 \\
$20-29$ & $113(39.6)$ & $29(10.2)$ & $53(18.6)$ & $90(31.6)$ & 285 \\
$30-39$ & $199(35.3)$ & $44(7.8)$ & $144(25.5)$ & $177(31.4)$ & 564 \\
$40-49$ & $109(38.0)$ & $41(14.3)$ & $29(10.1)$ & $108(37.6)$ & 287 \\
$50-59$ & $40(25.8)$ & $55(35.5)$ & $6(3.9)$ & $54(34.8)$ & 155 \\
$60-69$ & $25(25.3)$ & $45(45.5)$ & $3(3.0)$ & $26(26.3)$ & 99 \\
$70-79$ & $8(29.6)$ & $10(37.0)$ & $1(3.7)$ & $8(29.6)$ & 27 \\
Total & $562(37.4)$ & $226(15.1)$ & $239(15.9)$ & $474(31.6)$ & 1,501 \\
\hline
\end{tabular}

$95 \%$ CI $0.1-0.5, P<0.001)$ higher among those aged over 50 comparable to a younger age population. Genotype 3 was twice higher among those aged 20-40 year of age 
than the other age groups. Figure 2 shows the distribution of $\mathrm{HCV}$ genotypes among different age groups.

Figure 3 shows the influence of gender on the distribution of $\mathrm{HCV}$ genotypes among Libyans. Hepatitis $C$ virus genotypes, 1,4 and 3 are the common among both sexes. HCV-genotype 1 is highest among males (38.4\%), while genotype 4 is the highest among females (39.7 \%). HCV subtypes were also influenced by gender variations. Subtype $1 \mathrm{a}, 1 \mathrm{~b}, 1 \mathrm{a} / \mathrm{b}$, subtype $2 \mathrm{a} / \mathrm{c}, 3 \mathrm{a}, 4 \mathrm{a}$, $4 \mathrm{~b}$, $4 \mathrm{f}$ were found to be more common among males. Though subtype $2 \mathrm{a}$, subtype $4 \mathrm{~h}, 4 \mathrm{a} / \mathrm{c}$ and subtype $4 \mathrm{c} / \mathrm{d}$ were common among females. Hepatitis $\mathrm{C}$ genotypes vary from 1 year to another as shown in Fig. 4. Genotypes 1 and 4 we the commonly isolated one during the study period while genotypes 2 and 3 are slightly variable $(P>0.0025)$.
Table 3 shows the correlation between HCV-genotypes and the risk factors involved in the populations studied. HCV genotype 2 and genotype 3 were more frequent among intravenous drug abuse (IVDUs) comparable to non-users (non-IVUDs)-(IVUDs vs non-IVUDs) as it was found to be (49.2 vs $36.3 \%$ ) and (32.6 vs $14.3 \%$ ) respectively. Genotype 4 was more frequent among caesarean section comparable to those not operated (50 vs $14.3 \% ; P<0.0001)$. Non of other risk factor were found to be significantly associated with any of $\mathrm{HCV}$ genotypes $(P<0.26)$. Multiple risk factors were identified among $9.5 \%$ (6.1-2.3\% among the different age groups) of the subjects, where $7.4 \%$ of them had two risk factors and $2.1 \%$ had three risk factors. There are no risk factors found in $40.9 \%$ of the patients under the study ranging from 37.1 to $51 \%$ in the different age groups.

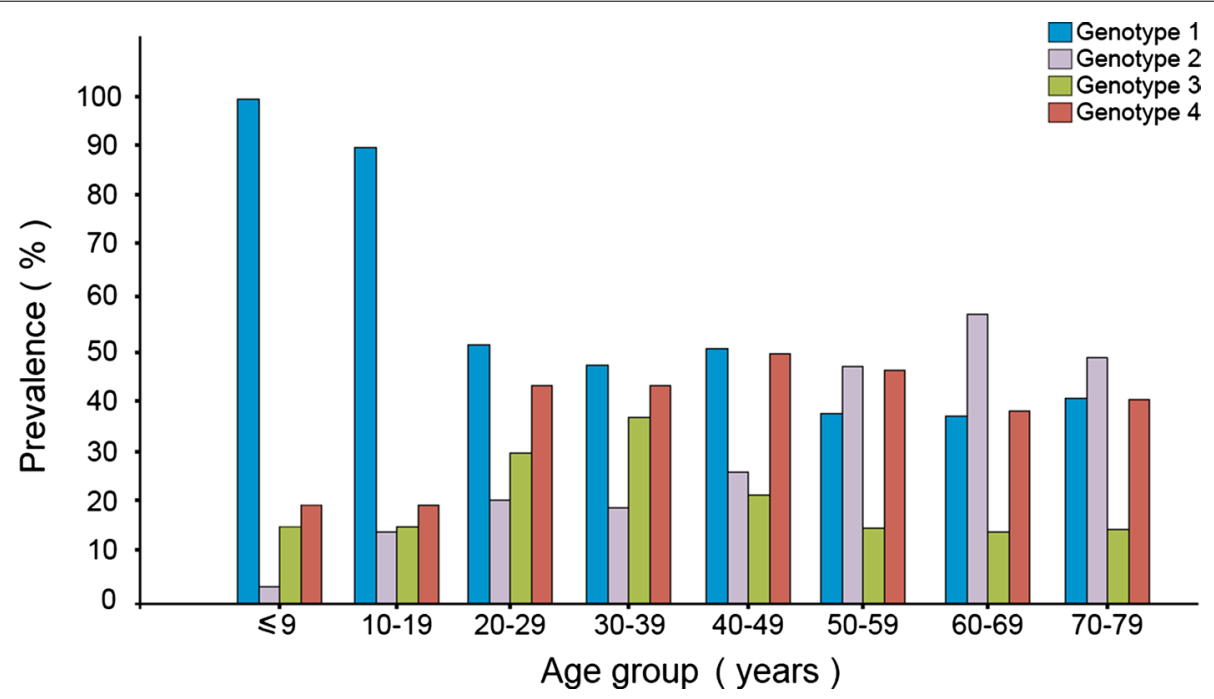

Fig. 2 The distribution of HCV genotypes among different age groups of Libyan populations.

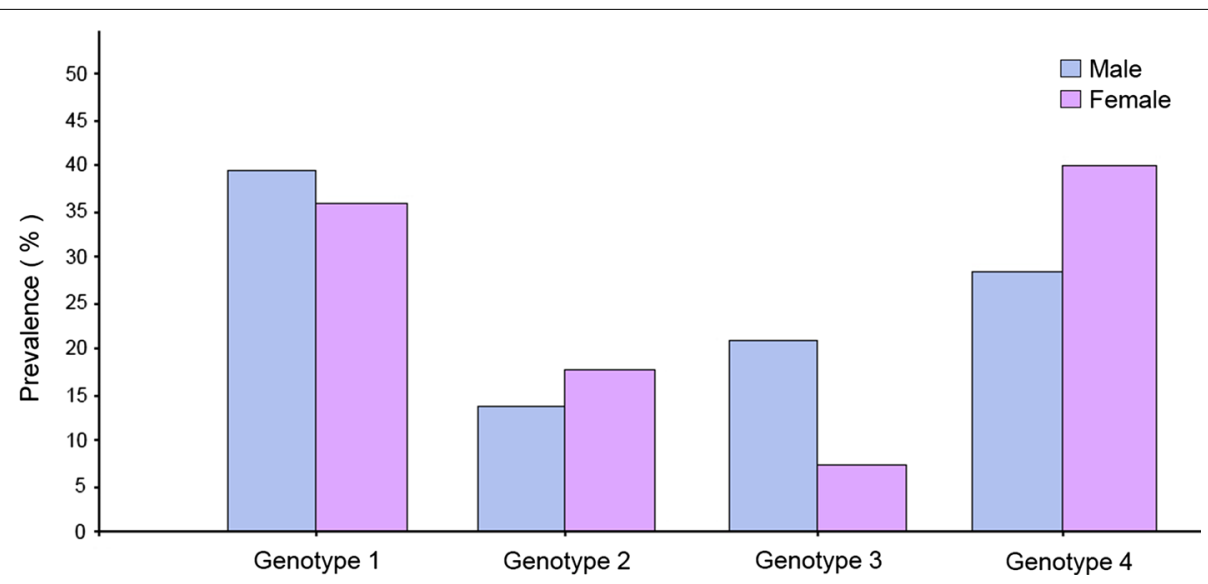

Fig. 3 The influence of gender on the distribution of HCV genotypes among Libyans. 


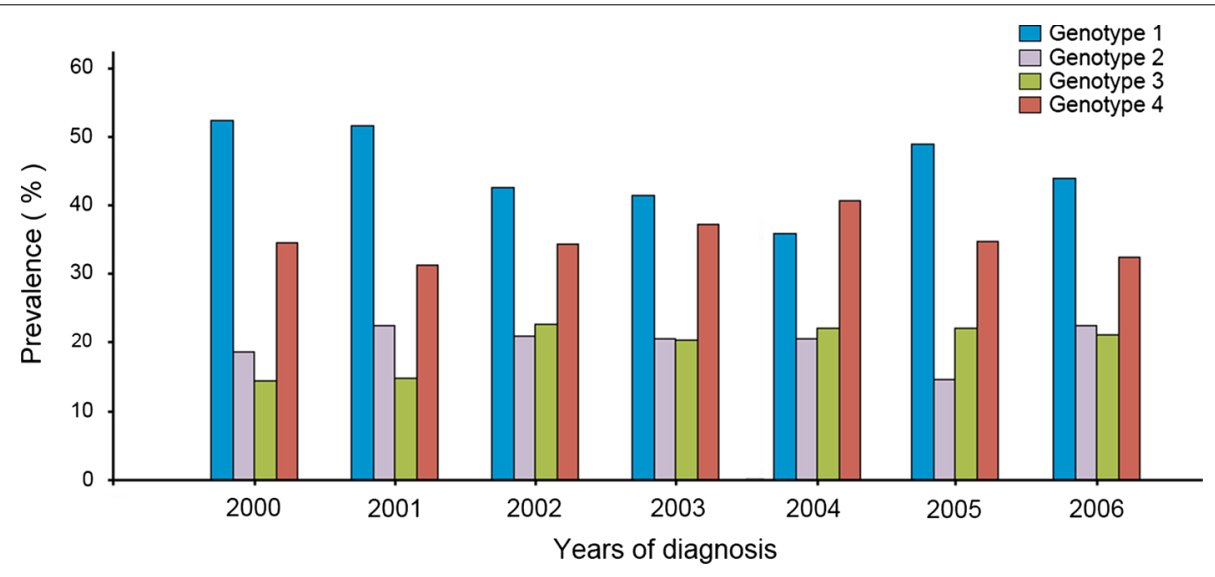

Fig. 4 Distribution of hepatitis C genotype during the period of 2000-2006.

Table 3 Prevalence of HCV Genotype according to risk factors among Libyan population, $* P=0.26$

\begin{tabular}{|c|c|c|c|c|c|c|}
\hline Risks exposure & Genotype 1 & Genotype 2 & Genotype 3 & Genotype 4 & Total & $P$ value* \\
\hline \multicolumn{7}{|l|}{ Sexual } \\
\hline No & $551(37.3)$ & $225(15.2)$ & $234(15.8)$ & $467(31.6)$ & 1,477 & 0.424 \\
\hline Yes & $11(45.8)$ & $1(4.2)$ & $5(20.8)$ & $7(29.2)$ & 24 & \\
\hline \multicolumn{7}{|l|}{ Cesarean section } \\
\hline No & $549(37.7)$ & $222(15.2)$ & $235(16.1)$ & $451(31.0)$ & 1,457 & 0.26 \\
\hline Yes & $13(29.5)$ & $4(9.1)$ & $4(9.1)$ & $23(52.3)$ & 44 & \\
\hline \multicolumn{7}{|c|}{ Intravenous drug use } \\
\hline No & $497(36.3)$ & $226(16.5)$ & $196(14.3)$ & $450(32.9)$ & 1,369 & 0.000 \\
\hline Yes & $65(49.2)$ & $0(0)$ & $43(32.6)$ & $24(18.2)$ & 132 & \\
\hline \multicolumn{7}{|l|}{ Blood transfusion } \\
\hline No & $420(37.1)$ & $167(14.8)$ & $196(17.3)$ & $348(30.8)$ & 1,131 & 0.071 \\
\hline Yes & $142(38.4)$ & $59(15.9)$ & $43(11.6)$ & $126(34.1)$ & 370 & \\
\hline \multicolumn{7}{|l|}{ Surgery } \\
\hline No & $457(38.1)$ & $171(14.3)$ & $198(16.5)$ & $372(31.1)$ & 1,198 & 0.165 \\
\hline Yes & $105(34.7)$ & $55(18.2)$ & $41(13.5)$ & $102(33.7)$ & 303 & \\
\hline \multicolumn{7}{|l|}{ Dental procedure } \\
\hline No & $490(37.5)$ & $193(14.8)$ & $204(15.6)$ & $418(32.0)$ & 1,305 & 0.641 \\
\hline Yes & $72(36.7)$ & $33(16.8)$ & $35(17.9)$ & $56(28.6)$ & 196 & \\
\hline \multicolumn{7}{|l|}{ Intrafamilial } \\
\hline No & $549(37.4)$ & $222(15.1)$ & $232(15.8)$ & $463(31.6)$ & 1,466 & 0.876 \\
\hline Yes & $13(37.1)$ & $4(11.4)$ & $7(20.0)$ & $11(31.4)$ & 35 & \\
\hline \multicolumn{7}{|l|}{ Haemodialysis } \\
\hline No & $551(37.5)$ & 225 (15.3) & 234 (15.9) & $460(31.3)$ & 1,470 & 0.185 \\
\hline Yes & 11 (35.5) & $1(3.2)$ & $5(16.1)$ & $14(45.2)$ & 31 & \\
\hline
\end{tabular}

\section{Discussion}

Hepatitis $C$ virus genotyping has been found to play an important role in understanding the epidemiology, guiding the clinical therapy, vaccine development and assessing the risk-benefit of $\mathrm{HCV}$ infection [26-28]. In recent decades there has been a global epidemic of some of these genotypes and subtypes assembled with certain risk factors and modern medical practice $[3,4]$. Regional differences appear to exist in the distribution of HCV genotypes. Such variability are rarely studied in Africa where habitual and ethnic variation exist and $\mathrm{HCV}$ is considered to be endemic [29]. Hence then studying distribution 
of various genotypes in this continent is essential for its prognostic implications in chronic hepatitis $\mathrm{C}$ infection.

In this cross-sectional epidemiologic study, with stratified sampling we investigated the distribution of various HCV genotypes in Libya, and the potential links with demographic and transmission risk factors. Our results indicate that HCV genotype $1(37.4 \%)$ is the most prevalent genotype cross Libya followed by genotypes 4 (31.6\%) and to less extent genotypes 3 and 2 and infrequent cases of genotype 5. This however, is in agreement in previous studies carried by our group though with a lower population size [20]. A substantial regional differences appear to exist in the distribution of $\mathrm{HCV}$ genotypes cross Libya. Genotype 1 and 3 were higher in Tripoli, and East regions though less among the others particularly south regions. Genotype 4 was higher in South and West regions while genotype 2 more prevalent in North and South regions. Such data correspondence well with other studies from different countries that have shown the genotypic regional diversity of HCV [30]. Genotypes 1 and 3 of Tripoli region were found to be similar to those in south Italy and Greece [31, 32]. Though genotype 4 of the South and East regions were also common in Egypt and other neighboring African countries [33]. Genotypes 2 and 3 were found to be more frequent in the South and North regions may suggest presence of foreigners living illegally in Libya, due to uncontrolled borders. Libya, however, is considered to be biggest seat for illegal transition immigration to EU particularly during the recent uprising and uncontrolled armed conflicts $[19,34]$. Thus knowledge on the distribution of various genotypes in such country is essential for its prognostic implications in chronic hepatitis $C$ infection. Hence then further study are needed to document the changes of HCV genotypes variability over periods of time.

The distribution of HCV genotypes in this study was influenced by gender. Genotypes 1 (M:F; 38.4:35.7 \%), 3 (20.8:6.9) and 4 (17.6:14) were higher among males. Although few distinct subtypes within genotype 4 were more predominant among females particularly $4 \mathrm{~h}$ (0.36:1.08) and 4c/d (1.32:3.81) while genotype 2 was more frequent among females (13.6:17.7). Our results are in concordance with a recently published data from other countries including Italy and Germany [35, 36]. However, most of those participated in the study were males (65:35). This may reflect the conservative nature of Libyan society and highlights the need to improve sampling techniques particularly among women sectors in the upcoming surveys.

Considering the age group distribution, the present study indicates that $\mathrm{HCV}$ genotype distribution varies with age. HCV genotype 1 is highly predominant among younger patients ( $<20$ years). It reached 88 and
$78 \%$ among those aged (0-9 years) and (10-19) respectively. Genotype 2 was tripled among those aged above 50 , although genotype 3 was significantly higher among those aged 20-40 years. Genotype 4 was evenly distributed in all age groups particularly over 20 years old. Different studies have analyzed the correlation of HCV genotypes in relation to the patients age. Similar results were also reported in other North African countries. In Algeria, genotype 1 is associated with the age group younger than 60 years though other genotypes types are higher among older age groups [37]. The frequency of genotypes and their variation according to age groups were clearly evident among the Libyan populations which was not reported before and thus appears to confirm the 'stratification' of genotypes associated with risk factors reported in the literature $[2,19,20]$.

Different studies have suggested HCV genotypes may be associated with different transmission routes and high risk behaviors. Transmission by IVDUs is most common in Libya, and has become more frequent and associated with genotype 1 (49.2\%) and genotype 3 (32.6 \%) infections. Studies from neighboring countries also found an association between genotype 1 and IVDUs but not genotype 3 . However, it has also been reported that $\mathrm{HCV}$ genotype 3 is particularly prevalent in intravenous drug abusers in Europe and the United States due to wide spread use of heroin [38, 39]. The identification of genotype 3 among Libyan population reflected its worldwide occurrence among PWID. Further studies are needed to highlight the spread of this genotype particularly among the young people. Genotype 4 was significantly associated with Caesarian section (52.3\%) and intra-family transmission (31.4\%). Both genotype 1 and 4 were the predominant genotypes among medical practice including blood transfusion $(1: 4 ; 38.4: 34.1)$, surgical practice procedures $(34.7: 33.1)$, dental practice $(33: 18.2)$ and haemodialysis (45.8:45.2). This is in agreement with other studies from different countries where majority of the cases with genotype 1 has a history of hospitalization for major/minor surgery, dental procedures, received blood and/or blood products and shaving by barbers [40-42].

In this study, over $15 \mathrm{HCV}$ subtypes were identified including newly emerged ones such as $1 \mathrm{a} / \mathrm{b}, 4 \mathrm{~b}, 4 \mathrm{e}, 4 \mathrm{f}, 4 \mathrm{~h}$, $4 a / c, 4 d, 4 c / d$ and HCV genotype 5. The distribution of these subtypes among the Libyan regions and their association with demographic and behavioral correlates were explored. Subtypes 1a, 1b and 3a are more predominant in Tripoli region (i.e. Old City and Bosleam) and East region (i.e. Benghazi) particularly among young males ( $<30$ years) with history of IVDUs. This is in an agreement with other studies from America and Southern Europe countries who also found a higher percentage of individuals infected with HCV subtypes 1a, 1b, and 3a, 
are among IVDUs $[43,44]$. HCV subtypes $4 \mathrm{a}, 4 \mathrm{e}, 4 \mathrm{~h}$ and $4 \mathrm{c} / \mathrm{d}$ more frequent in South and East regions of Libya and associated with hospital and modern medical practices. Genotype 4 is considered to be endemic in North Africa and Meddle-East and rarely reported in other regions and thus more likely to be associated with common public-health and family practices. However, further studies are needed to highlight the association of these subtypes with education levels and living standards conditions among such countries $[3,19]$.

Our study mirrors clearly the HCV genotypic diversity among Libyan populations. Such, genotyping profile variability may reflect differences in the timing of acquisition of HCV infection that may in turn influence the timing of the peak burden of $\mathrm{HCV}$ complications including cirrhosis and hepato-cellular carcinoma. As a consequence of these trends, regional differences in $\mathrm{HCV}$ genotype prevalence and epidemiology may warrant consideration of prevention and treatment strategies that are tailored to local needs [45].

The main limitations of this study that the correlation between HCV genotypes and the severity of the diseases among the studied population is lacking. Previous reports have shown that evidence of advanced liver disease and increased risk of hepatocellular carcinoma were more common in patients with HCV genotype 1 and $1 \mathrm{~b}$ than other genotypes $[46,47]$. Hence then future studies es are recommended to highlight such correlation particularly among naïve patients [48]. Additionally this study did not identify patients with possible $\mathrm{HCV} / \mathrm{HIV}$ co-infection and $\mathrm{HCV}$ genotypes involved. Different studies have shown that the distribution of HCV genotypes in the HIVinfected population reflects the route of transmission and progression to both AIDS and death [49]. Genotype 1b associated with post-transfusion HIV infections and genotypes 1a and 3a are more common in intravenous drug users infected with HIV [50]. Furthermore, genotype 1 and 3 were associated with severe histopathological and steatohepatitis findings in HIV/HCV-co-infected patients and leads to significantly faster HIV progression [51].

\section{Conclusion}

In conclusion regional difference in HCV genotypes were clearly evident among Libyan population with emerging of new genotypes, though genotypes 1 and 4 are more dominant. The frequency of these genotype are significantly associated with demographic and risk factors involved. Furthermore, the spread of intravenous drug use could have led to a new wave of HCV infection among young people. Therefore, a future evaluation of new 'emerging' subtypes over a period of time will be necessary, particularly nowadays as the country passing by difficult situations resulting in a massive population displacement and immigration engulfment [52].

\section{Authors' contributions}

MD designed the study, extracted the data, and drafted and finalised the manuscript. AE \& AD analyzed the data and contributed to the drafting of the data. All authors read and approved the final manuscript.

\section{Author details}

${ }^{1}$ Department of Medical Microbiology, Faculty of Medicine, Tripoli University, 82668 Tripoli, Libya. ${ }^{2}$ Libyan National Surveillance Studies of Viral Hepatitis \& HIV, Tripoli, Libya. ${ }^{3}$ Department of Laboratory Medicine, Faculty of Biotechnology, Tripoli University, 82668 Tripoli, Libya. ${ }^{4}$ Department of Surgery, Faculty of Medicine, Tripoli Medical Center, Tripoli, Libya.

\section{Acknowledgements}

We are deeply grateful to the Libyan Study Group of Hepatitis \& HIV and Department of Medical Microbiology and Immunology for their help in storing the serum samples collected for the study.

\section{Compliance with ethical guidelines}

\section{Competing interests}

The authors declare that they have no competing interests.

Received: 4 November 2014 Accepted: 30 July 2015

Published online: 21 August 2015

\section{References}

1. Daw MA, Dau AA, Agnan MM (2012) Influence of healthcareassociated factors on the efficacy of hepatitis C therapy. Sci World J 2012:580216

2. Szabo SM, Bibby M, Yuan Y, Donato BM, Jiménez-Mendez R, CastañedaHernández $G$ et al (2012) The epidemiologic burden of hepatitis $C$ virus infection in Latin America. Ann Hepatol 11(5):623-635

3. Daw M, Dau A (2012) Hepatitis C in Arab world: a state of concern. Sci World J 2012:719494

4. Young AM, Crosby RA, Oser CB, Leukefeld CG, Stephens DB, Havens JR (2012) Hepatitis C viremia and genotype distribution among a sample of HCV-exposed nonmedical prescription drug users in Rural Appalachia. J Med Virol 84(9):1376-1387

5. Jacobson IM, McHutchison JG, Dusheiko G, Di Bisceglie AM, Reddy KR, Bzowej NH et al (2011) Telaprevir for previously untreated chronic hepatitis C virus infection. N Engl J Med 364:2405-2416

6. Poordad F, McCone J Jr, Bacon BR, Bruno S, Manns MP, Sulkowski MS et al (2011) Boceprevir for untreated chronic HCV genotype 1 infection. N Engl J Med 364:1195-1206

7. Raimondi S, Bruno S, Mondelli MU, Maisonneuve P (2009) Hepatitis C virus genotype $1 \mathrm{~b}$ as a risk factor for hepatocellular carcinoma development: a meta-analysis. J Hepatol 50:1142-1154

8. Thomas DL, Astemborski J, Rai RM, Anania FA, Schaeffer M, Galai N et al (2000) The natural history of hepatitis C virus infection: host, viral, and environmental factors. JAMA 284:450-456

9. Thomas DL, Seeff LB (2005) Natural history of hepatitis C. Clin Liver Dis 9:383

10. Germer JJ, Mandrekar JN, Bendel JL, Mitchell PS, Yao JD (2011) Hepatitis $\mathrm{C}$ virus genotypes in clinical specimens tested at a national reference testing laboratory in the United States. J Clin Microbiol 49:3040-3043

11. Petruzziello A, Coppola N, Diodato AM, lervolino V, Azzaro R, Di Costanzo $G$ et al (2013) Age and gender distribution of hepatitis $C$ virus genotypes in the metropolitan area of Naples. Intervirology 56:206-212

12. Gededzha MP, Selabe SG, Kyaw T, Rakgole JN, Blackard JT, Mphahlele MJ (2012) Introduction of new subtypes and variants of hepatitis C virus genotype 4 in South Africa. J Med Virol 84:601-607

13. Dong ZX, Zhou HJ, Wang JH, Xiang XG, Zhuang Y, Guo SM et al (2012) Distribution of hepatitis $C$ virus genotypes in Chinese patients with chronic hepatitis C: correlation with patients' characteristics and clinical parameters. J Dig Dis 13(11):564-570. doi:10.1111/j.1751-2980.2012.00636.x

14. Yamada H, Fujimoto M, Somana S, Lim O, Hok S, Goto N et al (2014) Seroprevalence, genotypic distribution and potential risk factors of hepatitis $B$ and $C$ virus infections among adults in Siem Reap, Cambodia. Hepatol Res. doi:10.1111/hepr.12367 
15. Quan VM, Go VF, Nam LV, Bergenstrom A, Thuoc NP, Zenilman J et al (2009) Risks for HIV, HBV, and HCV infections among male injection drug users in northern Vietnam : a case-control study. AIDS Care 2(1):7-16

16. Tokita $H$, Okamoto $H$, lizuka $H$, Kishimoto $H$, Tsuda $F$, Lesmana LA et al (1996) Hepatitis C virus variants from Jakarta, Indonesia classifiable into novel genotypes in the second (2e and 2f), tenth (10a) and eleventh (11a) genetic groups. J Gen Virol 77:293-301

17. Toyoda H, Kumada T, Takaguchi K, Shimada N, Tanaka J (2014) Changes in hepatitis $C$ virus genotype distribution in Japan. Epidemiol Infect 5:1-5

18. Abdelwahab SF, Hashem M, Galal I, Sobhy M, Abdel-Ghaffar TS, Galal $\mathrm{G}$ et al (2013) Incidence of hepatitis C virus infection among Egyptian healthcare workers at high risk of infection. J Clin Virol 57(1):24-28

19. Daw MA, Shabash A, El-Bouzedi A, Aghnya A, Dau in association with the Libyan Study Group of Hepatitis \& HIV (2014) Seroprevalence of HBV, HCV \& HIV co-infection and risk factors analysis in Tripoli-Libya. PLoS One 9(6):e98793. doi:10.1371/journal.pone.0098793

20. Elasifer HA, Agnnyia YM, Al-Alagi BA, Daw MA (2010) Epidemiological manifestations of hepatitis $C$ virus genotypes and its association with potential risk factors among Libyan patients. Virol J 7:317

21. Daw M, Elkhammas E (2008) Libyan medical education; time to move forward. Libyan J Med 3:1-3

22. Rusine J, Ondoa P, Asiimwe-Kateera B, Boer KR, Uwimana JM, Mukabayire $O$ et al (2013) High seroprevalence of HBV and HCV infection in HIV-I infected adults in Kigali, Rwanda. PLoS One 8:e63303

23. Jobarteh M, Malfroy M, Peterson I, Jeng A, Sarge-Njie R, Alabi A et al (2010) Seroprevalence of hepatitis B and C virus in HIV-1 and HIV-2 infected Gambians. Virol J 7:230-239

24. Daw MA, El-Bouzedi A (2014) Prevalence of hepatitis B and hepatitis C infection in Libya: results from a national population based survey. BMC Infect Dis 14:17

25. World Medical Association Ethics Unit (2009) http://www.wma.net/ en/30publications/10policies/b3/index.html. Accessed 5 July 2015

26. Halliday J, Klenerman P, Barnes E (2011) Vaccination for hepatitis C virus: closing in on an evasive target. Expert Rev Vaccines 10:659-672

27. Pybus OG, Barnes E, Taggart R, Lemey P, Markov PV, Rasachak B et al (2009) Genetic history of hepatitis C virus in East Asia. J Virol $83: 1071-1082$

28. Simmonds P, Bukh J, Combet C, Deléage G, Enomoto N, Feinstone S et al (2005) Consensus proposals for a unified system of nomenclature of hepatitis C virus genotypes. Hepatology 42:962-973

29. Karoney MJ, Siika AM (2013) Hepatitis C virus (HCV) infection in Africa: a review. Pan Afr Med J 14(1):44. doi:10.11604/pamj.2013.14.44.2199

30. Idrees M, Riazuddin S (2008) Frequency distribution of hepatitis C virus genotypes in different geographical regions of Pakistan and their possible routes of transmission. BMC Infect Dis 2008(8):69

31. Cenci M, Massi M, Alderisio M, De Soccio G, Recchia O (2007) Prevalence of hepatitis $C$ virus (HCV) genotypes and increase of type 4 in central Italy: an update and report of a new method of HCV genotyping. Anticancer Res 27(2):1219-1222

32. Katsoulidou A, Sypsa V, Tassopoulos NC, Boletis J, Karafoulidou A, Ketikoglou l et al (2006) Molecular epidemiology of hepatitis C virus (HCV) in Greece: temporal trends in HCV genotype-specific incidence and molecular characterization of genotype 4 isolates. J Viral Hepat 13(1):19-27

33. Tanaka Y, Agha S, Saudy N, Kurbanov F, Orito E, Kato T et al (2004) Exponential spread of hepatitis C virus genotype 4a in Egypt. J Mol Evol 58(2):191-195

34. Dau AA, Tloba S, Daw MA (2013) Characterization of wound infections among patients injured during the 2011 Libyan conflict. East Mediter Health J 19:4-9

35. Pontisso P, Ruvoletto MG, Nicoletti M, Tisminetzky S, Gerotto M, Levrero $M$ et al (1995) Distribution of three major hepatitis $C$ virus genotypes in Italy. A multicentre study of 495 patients with chronic hepatitis. C. J Viral Hepat 2(1):33-38

36. Berg T, Hopf U, Stark K, Baumgarten R, Lobeck H, Schreier E (1997) Distribution of hepatitis $C$ virus genotypes in German patients with chronic hepatitis C: correlation with clinical and virological parameters. J Hepatol 26(3):484-491

37. Rouabhia S, Sadelaoud M, Chaabna-Mokrane K, Toumi W, Abenavoli L (2013) Hepatitis C virus genotypes in north eastern Algeria: a retrospective study. World J Hepatol 5(7):393
38. Matheï C, Buntinx F, Damme PV (2002) Seroprevalence of hepatitis C markers among intravenous drug users in western European countries: a systematic review. J Viral Hepat 9(3):157-173

39. Armstrong GL, Wasley A, Simard EP, McQuillan GM, Kuhnert WL, Alter MJ (2006) The prevalence of hepatitis $C$ virus infection in the United States, 1999 through 2002. Ann Intern Med 144:705-714

40. Hussain A, Idrees M (2013) The first complete genome sequence of HCV1a from Pakistan and a phylogenetic analysis with complete genomes from the rest of the world. Virol J 10:211

41. Alvarado-Mora MV, Moura IM, Botelho-Lima LS, Azevedo RS, Lopes E, Carrilho FJ et al (2012) Distribution and molecular characterization of hepatitis $C$ virus ( $\mathrm{HCV}$ ) genotypes in patients with chronic infection from Pernambuco State, Brazil. Virus Res 169(1):8-12

42. Skamperle M, Seme K, Lunar MM, Maver PJ, Tomažič J, Vovko TD et al (2014) Prevalence, genotype distribution, and risk factors for hepatitis C infection among HIV-infected individuals in Slovenia: a 1986-2013 update. Acta Dermatovenerol Alp Pannonica Adriat 23:25-26

43. Manos MM, Shvachko VA, Murphy RC, Arduino JM, Shire NJ (2012) Distribution of hepatitis $C$ virus genotypes in a diverse US integrated health care population. J Med Virol 84:1744-1750

44. Marascio N, Liberto MC, Barreca GS, Zicca E, Quirino A, Lamberti A et al (2014) Update on epidemiology of HCV in Italy: focus on the Calabria Region. BMC Infect Dis 14(Suppl 5):S2

45. Kabir A, Alavian S, Keyvani H (2006) Distribution of hepatitis C virus genotypes in patients infected by different sources and its correlation with clinical and virological parameters: a preliminary study. Comp Hepatol 5:4. doi:10.1186/1476-5926-5-4

46. Pawlotsky JM (2003) Hepatitis C virus genetic variability: pathogenic and clinical implications. Clin Liver Dis 7:45-66

47. Zein NN (2000) Clinical significance of hepatitis C virus genotypes. Clin Microbiol Rev 13:223-235

48. Daw MA, Elasifer HA, Dau AA, Agnan M (2013) The role of hepatitis C virus genotyping in evaluating the efficacy of INF-based therapy used in treating hepatitis C infected patients in Libya. Virol Discov 2013(1):3

49. Maier I, Wu GY (2002) Hepatitis C and HIV co-infection: a review. World J Gastroenterol 8:577-579

50. Rockstroh JK, Spengler U (2004) HIV and hepatitis C virus co-infection. Lancet Infect Dis 4(7):437-444

51. Garcia-Samaniego J, Soriano Y, Castilla J, Bravo R, Moreno A, Carbó J et al (1997) Influence of hepatitis C virus genotypes and HIV infection on histological severity of chronic hepatitis C. The hepatitis/HIV Spanish Study Group. Am J Gastroenterol 92:1130-1134

52. Daw MA, El-Bouzedi A, Dau AA (2015) Libyan armed conflict 2011: mortality, injury and population displacement. Afr J Emerg Med 2. doi:10.1016/j.afjem.2015.02.002

\section{Submit your next manuscript to BioMed Central and take full advantage of:}

- Convenient online submission

- Thorough peer review

- No space constraints or color figure charges

- Immediate publication on acceptance

- Inclusion in PubMed, CAS, Scopus and Google Scholar

- Research which is freely available for redistribution

Submit your manuscript at 